\title{
A COMPARISON OF THE VALUE OF CRYS- TALLOID SOLUTIONS, WHOLE BLOOD AND BLOOD PLASMA IN THE TREATMENT OF DEHYDRATION IN INFANCY *
}

\author{
BY \\ A. G. V. ALDRIDGE, M.A., M.D. \\ (From the Department of Diseases of Children in the University and the Children`s
} Hospital, Birmingham).

In an earlier communication (Aldridge, 1941) attention was drawn to the fact that in addition to water loss in dehydration in infancy, there is loss of electrolytes which may alter the acid base balance of the blood, and that oliguria may play a part in producing the condition. Treatment of dehydration is, therefore, designed to deal with these three factors; to this end fluid in excess of normal requirements (at least $2 \frac{1}{2}$ ounces per pound of body weight per day) must be administered, and if, as is usually the case, the patient does not take sufficient fluid by mouth, it must be given parenterally.

The common methods of administering fluid parenterally are the subcutaneous, intraperitoneal and intravenous routes. At the Birmingham Children's Hospital the subcutaneous and intravenous routes are used almost exclusively. The fluids used are normal ( 0.9 per cent.) saline solution and 5 to 10 per cent. solutions of glucose in sterile triply distilled water or in normal saline. Moderate degrees of dehydration are treated by giving normal saline as a continuous drip subcutaneously into the thigh, using between 100 and 150 c.c. ( 10 to 15 c.c. per pound of body weight). In children showing severe dehydration fluid, usually 5 or 10 per cent. glucose in saline, is given intravenously either in single doses of from 10 to 15 c.c. per pound of body weight or by continuous drip which is kept running for twenty-four, forty-eight or even seventy-two hours, depending on the condition of the patient. Although it has been the custom to give citrated blood to patients who do not respond to such treatment, the desirability of so doing is discussed in detail later in the paper.

\section{PARENTERAL INJECTION OF CRYSTALLOID SOLUTIONS IN DEHYDRATION}

Various authorities have advocated that these solutions should be given by combinations of the subcutaneous, intraperitoneal and intravenous routes, and

* Part of a thesis submitted for the degree of M.D., of the University of Cambridge. 
claims have also been made for the particular efficacy of solutions which contain bicarbonate, lactate, calcium and other substances. The use of fluids such as Hartmann's lactate-Ringer solution has been strongly recommended but this has not been used extensively at the Birmingham Children's Hospital. The impairment of renal function can only be relieved by an adequate intake of fluid, and the use of hypertonic glucose (10 per cent.) intravenously is almost universally commended as a diuretic. Notwithstanding the importance of treating renal impairment, it is a matter of urgency to replenish the fluid which has been lost and it must not be forgotten that the prolonged administration of any hypertonic solution intravenously may, through its diuretic action, actually increase dehydration. For this reason most observers advise the use of normal saline subcutaneously in conjunction with 10 per cent. glucose intravenously especially because glucose is said to aid absorption of saline.

The various methods advised for the treatment of the dehydration of infantile gastro-enteritis aim at replacing those substances, such as water and salts, which have been lost as the result of diarrhoea and vomiting. Many writers have stated that since bicarbonate and chloride are lost in this way, these substances, along with an adequate amount of water, should be given as part of the routine treatment. In practice, however, it is found to be unnecessary always to administer sodium bicarbonate as it is the $\mathrm{Na}$ rather than the $\mathrm{HCO}_{3}$ which has to be replaced. Therefore, normal saline alone is given parenterally on the assumption that if the body be given both $\mathrm{Na}$ and $\mathrm{Cl}$ it will keep whichever it requires and eliminate the other in the urine provided the kidneys are functioning actively.

Of twenty-one cases of gastro-enteritis examined prior to treatment, only three had low plasma chloride values, a finding which raised the question as to the necessity of giving chloride to such cases, and as to the effect on the plasma chloride of saline administration. It seemed illogical to give additional chloride as a routine to cases of dehydration no matter whether the increase of chlorides was actual or merely relative. In pyloric stenosis, on the other hand, normal saline appeared to be the ideal fluid for parenteral administration, since the plasma chlorides are invariably lowered in this disease.

Subcutaneous therapy. As an adjunct to other treatment normal saline was given subcutaneously to fourteen dehydrated children and the changes in the blood are summarized in table 1 . The blood was examined before and within the twenty-four hours following this administration. In half the children clinical improvement occurred and the red cell count, haemoglobin concentration and haematocrit readings were reduced in every patient. Chemical investigations showed that although there was a fall in the plasma chloride values in four instances, there was a rise in all other cases, in one the value being as high as $818 \mathrm{mgm}$. per 100 c.c.; also, that the concentration of plasma protein usually decreased, although this was not so marked as the reduction in red cells, haemoglobin and haematocrit.

Intravenous therapy. The results of examination of the blood chemistry before and after intravenous therapy in thirteen cases of dehydration following gastro-enteritis are shown in table 2. Clinical improvement was apparent in 


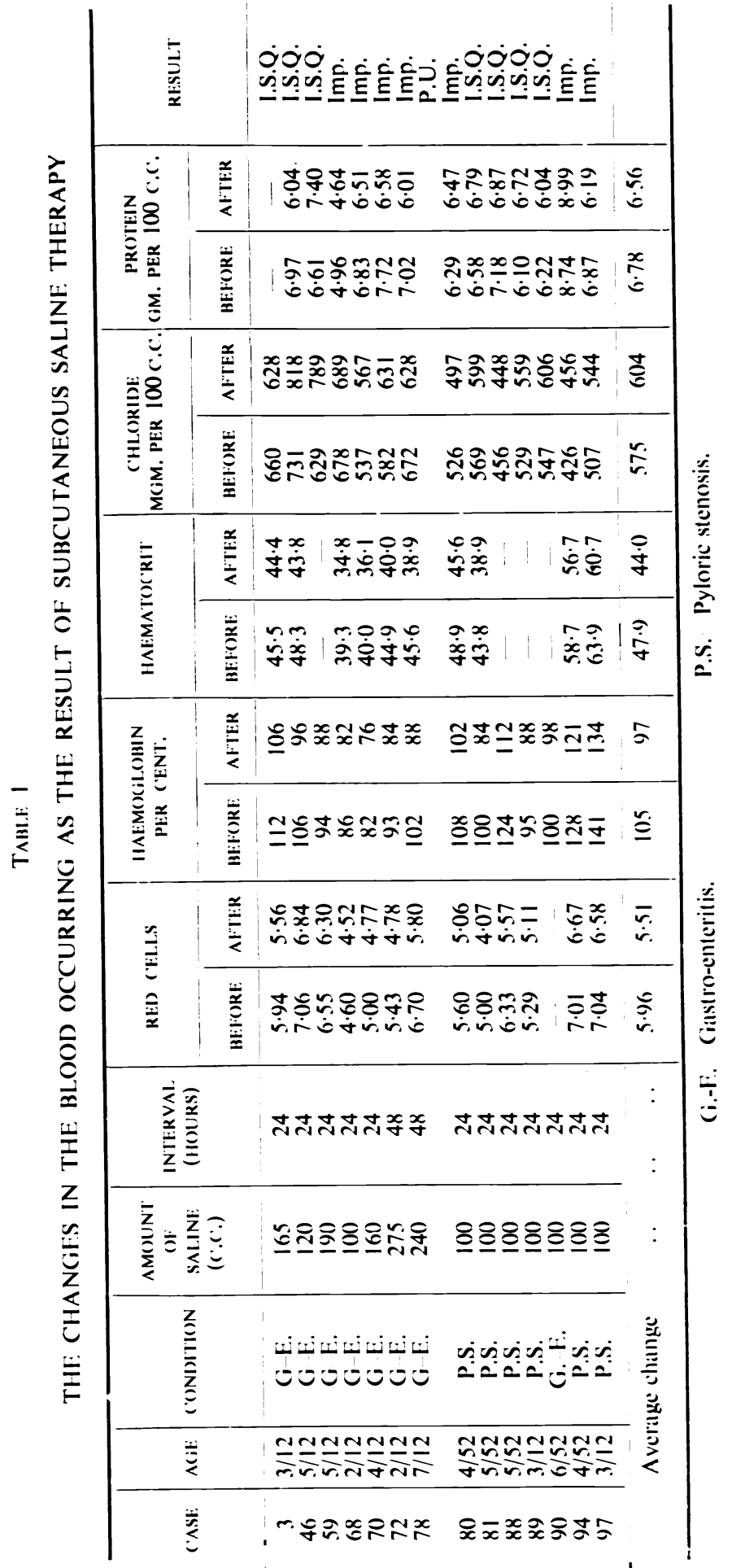


nine patients, three were unchanged, and one was worse after treatment. In every instance the red cell, haemoglobin and haematocrit readings fell. With two exceptions the plasma chloride values were increased despite the fact that one case received fluid which contained no chloride. In ten infants the final plasma chloride was over $\mathbf{7 0 0}$ mgm. per cent., but this did not appear to affect the patient adversely. The plasma protein was decreased in twelve of the thirteen cases.

\section{The changes in plasma chloride after parenteral therapy}

The effect of parenteral therapy on plasma chlorides deserves further attention, especially as many authorities state that administration of normal saline is essential in restoring electrolytes lost by the body, and also that such treatment does not raise the blood chlorides.

Six of the patients reported in table 1 were suffering from untreated pyloric stenosis and the others from gastro-enteritis. Only one case of pyloric stenosis had a normal initial plasma chloride value; in all other cases it was well below normal. Whereas in four instances the chloride rose to normal after the administration of subcutaneous normal saline, in two it fell still further, presumably as a result of continued vomiting. In both these infants the plasma chloride values rose to within normal limits after operation. On the other hand, before treatment four of the babies with gastro-enteritis had high chloride values, two normal values and two low values. A fall in the level of the plasma chloride followed the administration of saline subcutaneously in two of the four cases with high initial values; in one this was almost certainly due to the diuresis which occurred between the examination of the two blood samples. In the other two cases the plasma chloride readings increased to 818 and $689 \mathrm{mgm}$. per 100 c.c. respectively. In another case they rose from 629 to $789 \mathrm{mgm}$. per cent. in twenty-four hours. In those infants who received intravenous saline therapy (table 2) the plasma chloride rose to even higher values than in those which had been given normal saline subcutaneously. In nine cases in which the chloride was above normal before treatment, the final value averaged $63 \mathrm{mgm}$. per cent. higher. Although Hoag and Marples (1931) found that ... 'vigorous treatment with parenteral fluids, including large amounts of sodium chloride, produced no significant elevation of the chloride content of the blood,' and McIntosh and his colleagues (1930-31) made similar observations, the vast maiority of workers hold that the administration of large amounts of saline not only increases the plasma chloride but also causes acidosis. The discrepancy may be due to the fact that both groups of investigators delayed too long before the second examination of the blood (an average of twelve days after treatment in McIntosh's cases). My observations on the blood changes were made in almost every case from day to day over a considerable period of time, in some cases for two, three or even four weeks. In such cases the values of the plasma chloride increased as a result of treatment with parenteral normal saline, and decreased later in those cases which recovered. In view of the 


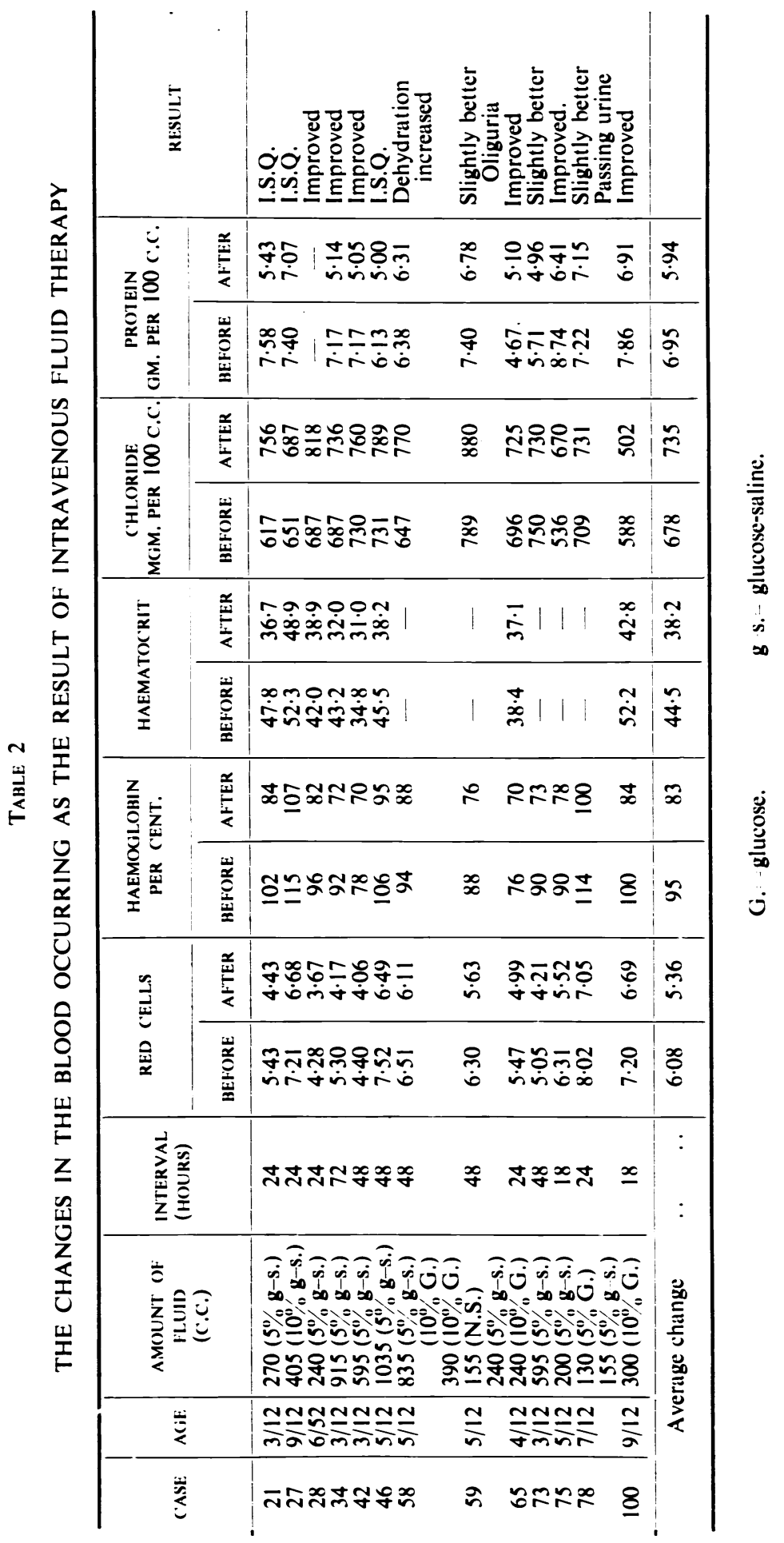


statement by Boyd (1926) that the height of the plasma chloride is of no prognostic value in untreated cases, it is of interest to note the value of the plasma chloride in a few fatal cases of gastro-enteritis. All these cases were given fluid containing chloride parenterally, and almost invariably became progressively more dehydrated before they died. The findings in a few such cases are represented graphically in fig. 1 , together with the values found on the day or two

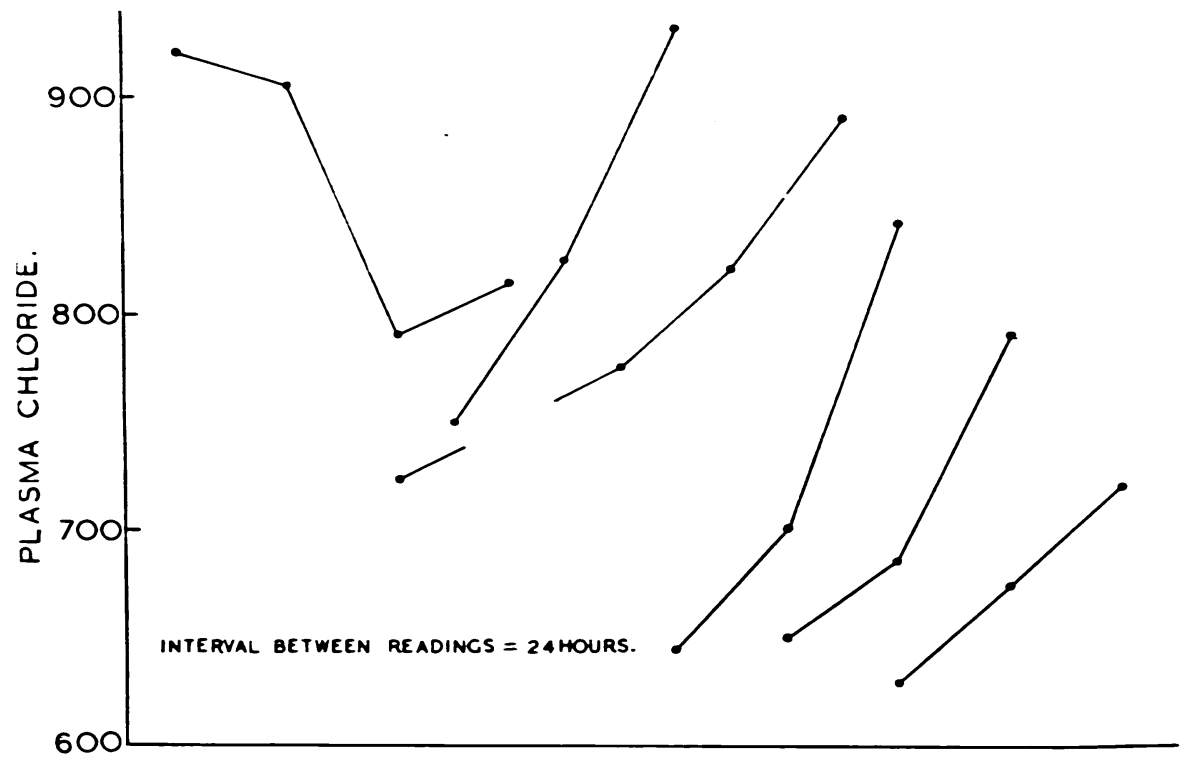

FIG. 1.-Plasma chloride values in fatal cases of gastro-enteritis in the few days immediately preceding death.

immediately preceding death. The average value of sixteen such cases was 765 mgm. per cent. $\mathrm{NaCl}$.

It is important to find the explanation of the high blood chloride in the dehydration of gastro-enteritis, and its further increase as the result of treatment, since it has been demonstrated by Gamble and Ross (1924-5) that when sodium chloride is administered for dehydration, the body is able to keep the ion of which it is most in need, and, provided that renal function is active, can excrete the other in the urine.

\section{The excretion of chloride}

In the normal individual chloride is almost entirely eliminated through the kidneys and only an insignificant amount in the stools, but the fluid stools of diarrhoea may contain as much as $15 \mathrm{gm}$. of $\mathrm{NaCl}$ per litre. The loss of chloride in insensible perspiration is negligible and is even less than normal in dehydrated infants. The chloride output in the urine and stools of five normal and eight dehydrated infants was determined by Hoag and Marples (1931); their average results which are given in table 3 show that even in diarrhoea most of the chloride is excreted in the urine. 
TABLE 3

THE AVERAGE OUTPUT OF CHLORIDE IN THE URINE AND STOOLS IN FIVE NORMAL AND EIGHT DEHYDRATED INFANTS (HOAG AND MARPLES, 1931)

\begin{tabular}{|c|c|c|c|c|}
\hline & & $\begin{array}{l}\text { LRINE OLTPUT } \\
\text { IN } 24 \text { HOURS }\end{array}$ & $\begin{array}{c}\text { CRINARY CHLORIDE } \\
\text { IN } 24 \text { HOURS }\end{array}$ & $\begin{array}{c}\text { FAECAL CHLORIDE IN } \\
24 \text { HOLRS }\end{array}$ \\
\hline Normal .. & . & 399 c.c. & 930 mgm. & $100 \mathrm{mgm}$. \\
\hline Dehydration & . & 327 c.c. & $1218 \mathrm{mgm}$. & $808 \mathrm{mgm}$. \\
\hline
\end{tabular}

Elimination of chloride is controlled by the needs of the body. Withdrawal of salt from an otherwise normal diet is followed by reduction of plasma chloride to about $560 \mathrm{mgm}$. per cent. $\mathrm{NaCl}$ at which level excretion in the urine stops so that a constant plasma value is maintained. Additional salt augments the rate of chloride excretion and raises the concentration of plasma chloride but to a surprisingly small degree in normal adults.

In spite of the fairly wide normal variation of plasma chloride (560 to $630 \mathrm{mgm}$. per 100 c.c.) it has been customary to speak of chloride as a threshold substance similar to glucose. Ambard (1920) worked out a formula for the excretion of threshold substances which is said to hold good for the same individual or for persons of the same body weight. This is as follows:-

$$
\frac{\text { Concentration of excess over threshold }}{\text { Rate of excretion } x \text { Concentration of urine }}=K \text { (a constant). }
$$

Aitken (1929) found that the nearest approximation to a renal threshold for chloride appears to be in the neighbourhood of 0.555 to 0.585 per cent. of plasma $\mathrm{NaCl}$, where the above relationship is rapidly altering. There is no evidence that this neighbourhood is constant under varying physiological conditions. It is suggested that the idea of a renal threshold for chloride be abandoned.' This suggestion is supported by the few cases investigated in which there appeared to be no relationship between the excretion of chloride and the height of the plasma chloride. As a matter of fact, there is little in the literature about the normal kidney function in young infants and this has recently been the subject of investigations by McCance and Young at the Birmingham Children`s Hospital, whose results are to be published shortly. Since this work of McCance and Young had not then been started, and no reference could be found to the relationship between intake of chloride and urinary output in normal infants, the intake and output of both water and chloride were estimated in a normal bottle-fed baby aged three months and the results are set out in fig. 2. This infant was taking milk and water feeds. 3 ounces three hourly, seven feeds per day, with an extra 1 to 2 ounces of boiled water during the night when necessary. Observations were made on the intake of fluid, the output of urine, the intake and output of chloride reckoned as $\mathrm{NaCl}$, the haemoglobin concentration, plasma chloride and protein, and the clinical condition of the child. For three days he was given his normal feeds. 
and daily estimations were made of the chloride content of the milk feeds. The individual values were $28 \cdot 8,28 \cdot 1$ and $28 \cdot 1 \mathrm{mgm}$. per ounce of feed on the three consecutive days-an average of $0.6 \mathrm{gm}$. per twenty-four hours. On the two

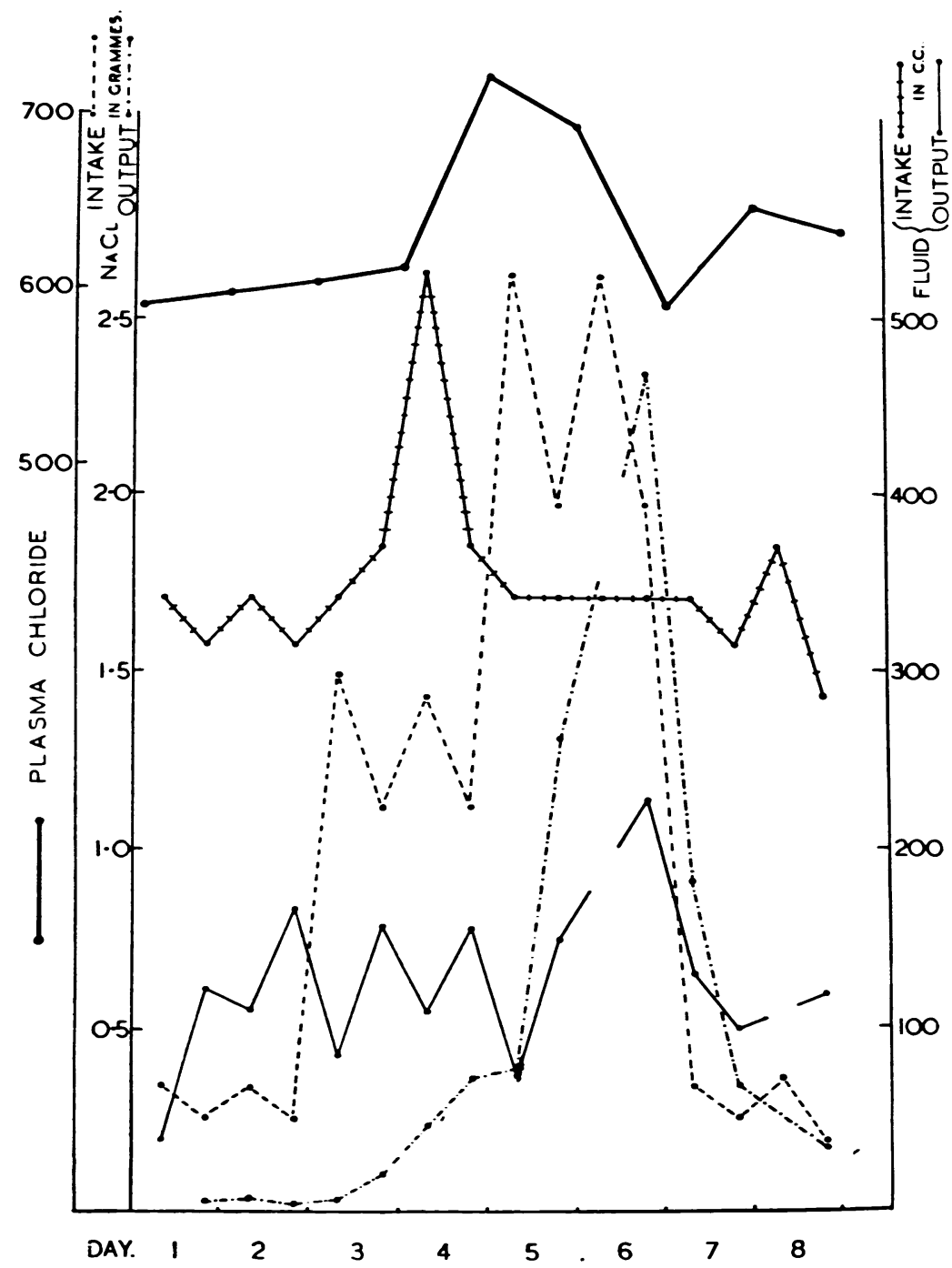

FIG. 2.-Graphic representation of the relationship between intake of chloride and urinary output in a normal child aged three months. The heavy continuous line represents the plasma chloride values. The crossed black line represents the intake of fluid in c.c. The light continuous line represents the output of urine in c.c. The dashed line represents the intake of sodium chloride in grammes. The dot and dash line represents the output of $\mathrm{NaCl}$ in grammes.

succeeding days, $2 \mathrm{gm}$. of $\mathrm{NaCl}$ were added to the twenty-four hour's feed, so that the intake of chloride was $123 \mathrm{mgm}$. per ounce of feed. The baby took the feeds quite well, and apart from being rather irritable and thirsty for twentyfour hours, appeared to be none the worse. During the subsequent two days 
$4 \mathrm{gm}$. of $\mathrm{NaCl}$ were added to the feeds for twenty-four hours, and for the remaining days on which he was examined no additional $\mathrm{NaCl}$ was given. In the graph the plasma chlorides and other constituents of the blood are shown as the value at $10.0 \mathrm{a} . \mathrm{m}$. on each day. The other estimations, being entirely quantitative, are divided into two twelve-hour estimations; the advantage of so doing is especially noticeable in the case of the urine volume. The actual collection of urine was always the most difficult procedure, and occasionally specimens were upset or voided into the bed, but working on a twelve hour basis meant that the loss of a specimen only affected the estimations over half a day. Unfortunately, the only important specimen lost in the case under consideration was that of the first period of the sixth day, quite the most important specimen of all. At this point the intake of chloride was at a maximum, the intake of fluid had fallen to normal, the output of chloride was increasing to its maximum, and the plasma chlorides were returning to their previous level; indeed, the concentration of chloride in the urine was $1 \cdot 39$, only just below the usually accepted maximum concentration at which the kidney excretes chloride ( 1.5 to 2.0 per cent.).

There are several features of interest about this case. First, the oral intake of fluid is about two-and-a-half times as large as the output of urine over the same period. As the chloride in the diet was increased, the infant became distressed and extremely thirsty. It would have been interesting to withhold water at this stage, but, anticipating the thirst, orders had been given that the child was to have as much extra water as he wanted. In spite of the greatly increased fluid intake on the fourth day, it was not until forty-eight hours later that diuresis occurred, although the concentration of chloride in the urine had been steadily increasing since the administration of the extra amount. The water taken had presumably been stored in the tissues with the excess of $\mathrm{NaCl}$ in order to keep the extra-cellular body fluids isotonic. The child almost certainly gained two or three pounds in weight at this stage, and lost them again when he had the diuresis, but unfortunately daily weighings were not carried out lest specimens of urine should be lost. Similar effects from excess $\mathrm{NaCl}$ by mouth have been described by de Wesselow (1924) and also by Junkenitz (Peters, 1935) who remarked that since he had found only a slight increase in the plasma chloride ( $24 \mathrm{mgm}$. per cent.) the blood must have been diluted by fluid from the tissues. In the present case the plasma chloride rose from 600 to $700 \mathrm{mgm}$. per cent. $\mathrm{NaCl}$, but rapidly became normal after the excess of chloride had been removed in the urine.

Another and most important point in the consideration of the question of administering chloride to cases of diarrhoea and vomiting with dehydration is illustrated in the graph (fig. 2). On the fifth, sixth and seventh days, the concentration of chloride in the urine was greater than that in the feeds, and at one point almost reached the maximum value possible ( 1.5 per cent.) although the concentration in the feeds only reached $\mathbf{0 . 7 5}$ per cent. on two successive days. Since the urinary output is considerably less than the fluid intake, if nothing but normal saline were administered it would be quite impossible for the body to get rid of the excess chloride because if not more than one half of the amount of water 
taken in by mouth is excreted through the kidney, then the concentration of chloride in the urine would have to be at least twice as great as its concentration in the oral fluid; thus, if the only fluid given is normal saline $(0.9$ per cent.) the concentration of chloride in the urine must be at least 1.8 per cent., a figure that is above the usually accepted maximum of 1.5 per cent. If there is oliguria. chloride retention is certain, and if there is also a water deficit the concentration of chloride in the blood must rise, yet despite these facts, infants who are unable to take fluid by mouth because of vomiting are frequently given large quantities of normal saline parenterally. For instance, a patient who was put on a continuous intravenous drip infusion of 5 per cent. glucose in normal saline, received 1190 c.c. in just over three days. The output of urine increased, but although the concentration of chloride in the urine increased from 0.03 to 1.4 per cent., the plasma chloride continued to rise (fig. 3) until the child died.

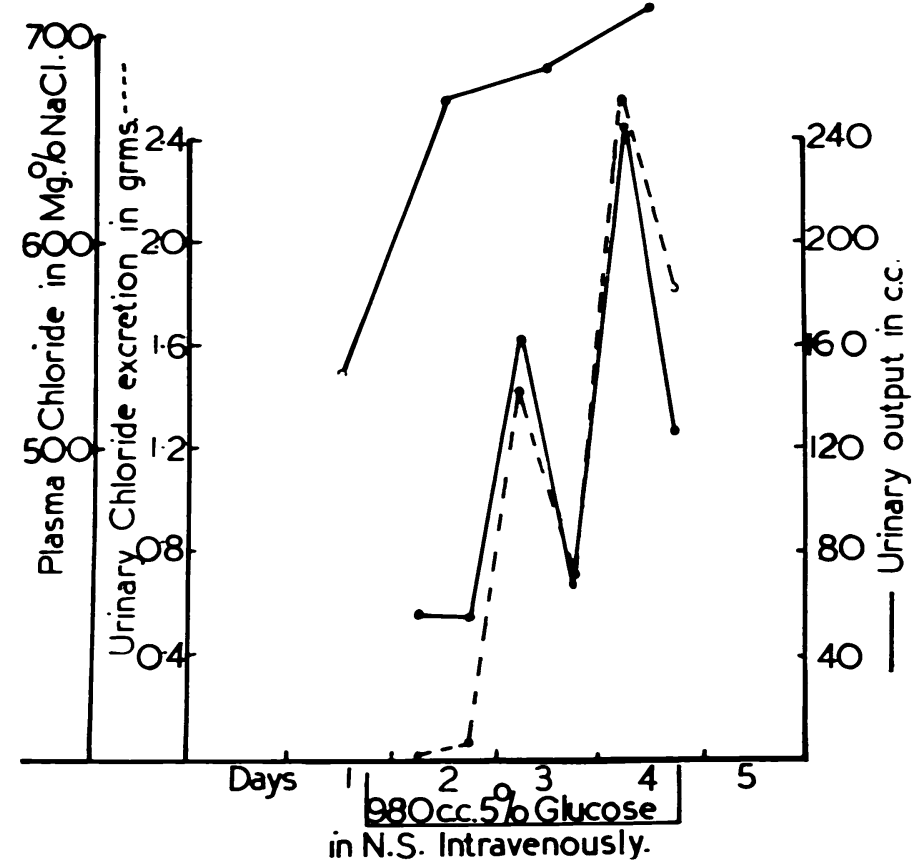

FIG. 3.- Chart showing increasing plasma chloride following intravenous injection of 5 per cent. glucose in normal saline, despite the increase in urinary flow and increased concentration of chloride in the urine.

As a result of these investigations it was decided that the routine administration of fluids containing normal saline was both illogical and unsafe; nevertheless, there are cases of gastro-enteritis which need chloride, and the only way to determine when this treatment should be used is by carrying out frequent examinations of the blood.

For the relief of oliguria the fluid of choice must not only be such as to supply water to the organism to counteract dehydration, but must also assist in restoring the disordered blood chemistry to normal, chiefly by virtue of its diuretic action. For this purpose, hypertonic glucose ( 10 per cent.) is most commonly 
used and was given to a few patients. Its action is well shown in fig. 4: after twenty-four hours oliguria ( 9.6 c.c. of urine only), 260 c.c. of 10 per cent. glucose were given intravenously; there was an immediate diuresis which was maintained by subsequent administration of 380 c.c. of 5 per cent. glucose in normal saline intravenously, together with saline given subcutaneously. A large amount of chloride was excreted in the urine, and the plasma chloride which had risen above normal fell to within normal limits.

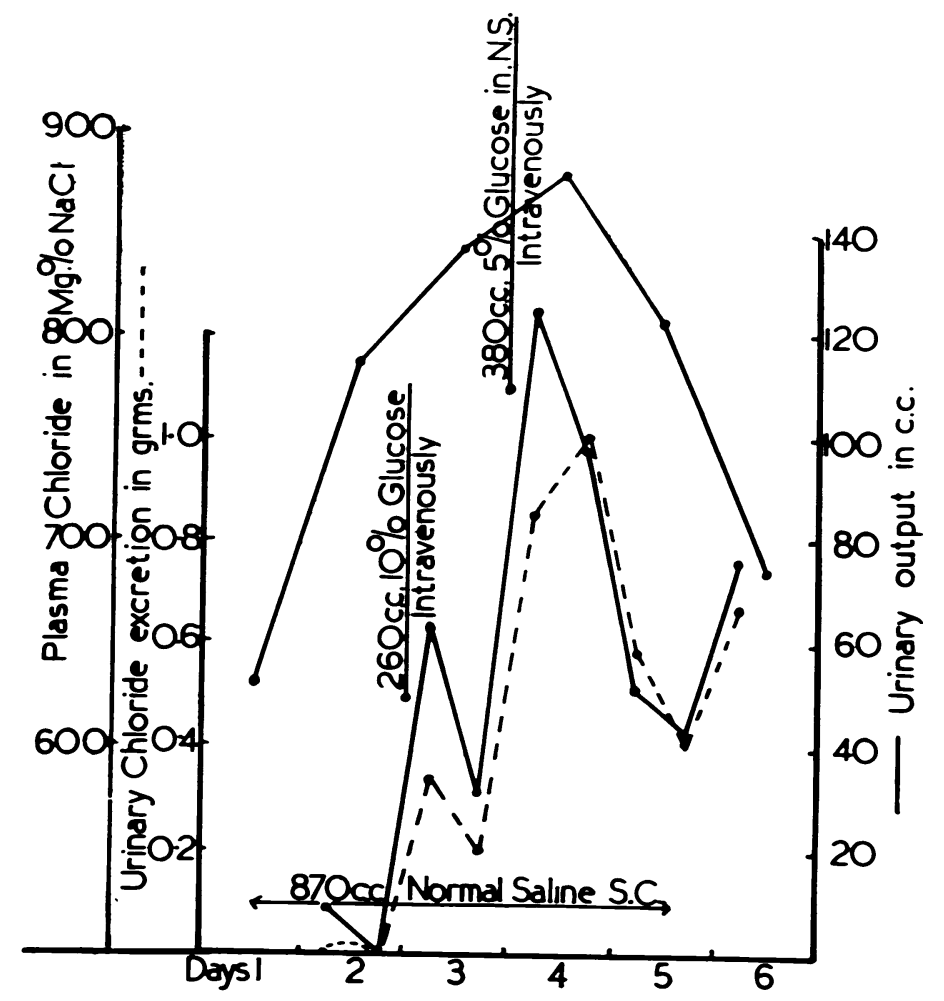

FIG. 4.-Showing the effect of intravenous administration of hypertonic glucose, 5 per cent. glucose in normal saline, and saline subcutaneously, on the quantity of urine secreted and on urinary and plasma chloride.

There are, however, two objections to the haphazard intravenous infusion of 10 per cent. glucose. First, it is possible to remove chloride from the organism, even when there is not an accumulation of chloride in the blood, and hence the plasma chloride may fall considerably below normal. If this were allowed to continue so much chloride might be lost that tetany might ensue, as in the case of pyloric stenosis. In one patient this treatment reduced the plasma chloride from 588 to $502 \mathrm{mgm}$. per 100 c.c. $\mathrm{NaCl}$, although tetany has not been observed. Secondly, by producing a marked diuresis in a patient who can only take a little fluid by mouth and is also losing much fluid as the result of diarrhoea, the use of 10 per cent. glucose solution may increase the degree of dehydration. Such a result was seen in a child after the administration of 160 c.c. of the glucose intravenously. This child was able to take only $11 \frac{1}{2}$ 
ounces of fluid orally during twenty-four hours, but in the twenty-four hours after infusion he passed 4 ounces of urine; although his clinical condition remained unchanged, examination of the blood showed that red cells and haemoglobin concentration had risen from 7,170,000 and 100 per cent. to $8,020,000$ per c.mm. and 114 per cent. respectively. Subsequently he improved rapidly after he had been given 5 per cent. glucose in water in half-normal saline intravenously, together with normal saline subcutaneously. Many authorities advocate the combined use of these solutions; certainly this method does away with many of the pitfalls of parenteral fluid therapy, and has proved the most suitable fluid for routine intravenous therapy in dehydration.

Finally, there are two other objections to the use of a large volume of fluid intravenously in treatment of dehydration. First, the plasma protein may fall considerably, and secondly, oedema of the intestinal mucosa may occur and lead to intensification of the diarrhoea (Karelitz, 1931).

\section{BLOOD TRANSFUSION IN THE TREATMENT OF DEHYDRATION}

Historical. During the past ten or fifteen years many authorities have recommended transfusion of whole blood in the treatment of the dehydration which arises from gastro-enteritis in infancy, some recommending transfusions as a routine procedure and others reserving their use for cases which failed to respond to other therapy.

Marriott (1934) advised blood transfusion in cases of chronic anhydraemia in order to restore to normal the blood volume which had been reduced by the destruction of red cells and plasma protein. Powers (1926) described blood transfusion as the most potent method of treatment for - alimentary intoxication 'recommending its use almost as a routine about an hour after the parenteral administration of other fluids and, if necessary, repeating it at intervals of twenty-four hours. In the same year, Carlton suggested that a blood transfusion should be given to all infants with "acute intestinal intoxication.' In his series of 139 cases. 70 per cent. were improved and the ultimate mortality rate was reduced to 37 per cent. Similar approval was expressed by Sidbury (1927) who described a series of 111 cases with a mortality figure of only 28 per cent.; he also suggested the preliminary administration of fluid, presumably intravenously, if the infants were very dehydrated. Johnson (1931) reduced his mortality rate in gastro-enteritis from 78 per cent. to 64 per cent. by means of transfusion, and Karelitz (1931) claimed improvement in all of thirty cases of " alimentary intoxication ' treated with 5 per cent. glucose in normal saline followed by blood transfusion. Thomson (1935) advocated the use of transfusion in marasmic children who were not progressing, but he found that it often gave disappointing results in the extreme stages of gastro-enteritis.

Butler (1935) and also Marriott and Hartmann (1933) advised the use of blood transfusion to raise the plasma protein when for any reason this was low, but the latter workers pointed out that in dehydrated infants whose plasma protein was already high as the result of fluid lost from the blood, transfusion might raise the protein to an even higher level, and so cause embarrassment to the circulation. The use of blood transfusion was advised by Holt and McIntosh (1933), ' since the fluid is retained for a longer time,' and Spence (1933) stated that it might be of great therapeutic value in advanced cases of gastro-enteritis, whilst Brown and Tisdall (1937) recommended its use if there 
was any marked drowsiness. Wiener (1935) expressed the opinion that although of little value when used alone, blood transfusion played a part in retaining the body fluids when used in conjunction with the administration of normal saline and glucose solutions. Maizels and Smith (1934), on the other hand, reported twenty cases of severe gastro-enteritis treated with blood transfusion of which only three improved clinically, and Cooper (1937) found the results disappointing in eighteen cases of acute gastro-enteritis. He suggested that blood transfusion was most useful in cases of chronic diarrhoea in which the blood was actually lacking in red cells and plasma protein, but he also pointed out that there was a danger of causing an increase in the protein by the administration of blood to infants suffering from acute diarrhoea.

The results and mortality figures reported by writers therefore vary greatly and Johnson (1931), when discussing • alimentary intoxication," makes the pertinent observation that when some authors say that the disease is almost always fatal, and others report 75 per cent. recoveries, it is evidence that they do not include the same type of case in their studies. Theoretically, at least, blood appears to be the ideal fluid to give dehydrated infants with gastro-enteritis. The diminished volume of circulating blood is thereby increased; moreover colloid suspensions, such as blood, are said to attract fluids into the circulation and to retain them more efficaciously than do crystalloid solutions, such as glucose and saline. Blood supplies food to the organism and the antibodies which it contains assist in combating any infection from which the recipient may be suffering: furthermore, whole blood is a physiological fluid. On the other hand, the question arises as to whether the administration of whole blood to a child whose blood is already concentrated will not increase the degree of haemo-concentration and so cause deterioration of the clinical condition. It is obvious that the red cell count, haemoglobin concentration and haematocrit reading rise after transfusion in anaemic patients, and the extent to which this occurred in twelve children of all ages is shown in table 4 . It is of interest to note that the average change in the plasma protein was a slight fall, although in those cases in which the donor's blood was examined the plasma protein was not found to be unduly low.

\section{Investigation}

During recent years at the Birmingham Children's Hospital, blood transfusions have been given to dehydrated infants suffering from gastro-enteritis. and although a small number improved rapidly after this treatment the majority did not, and actually became worse. In a few instances, death occurred within a few hours of transfusion, and in the course of a single year three infants died during or immediately after this treatment. In the light of such results the wisdom of giving transfusions of whole blood to dehydrated infants was considered, and also the reason why some children showed deterioration in the general condition, whereas others improved. To this end, investigations were carried out similar to those used in the enquiry into the effects of parenteral fluid therapy; thus changes in the red cell count, haemoglobin concentration. haematocrit reading and plasma protein content were studied. These observa- 


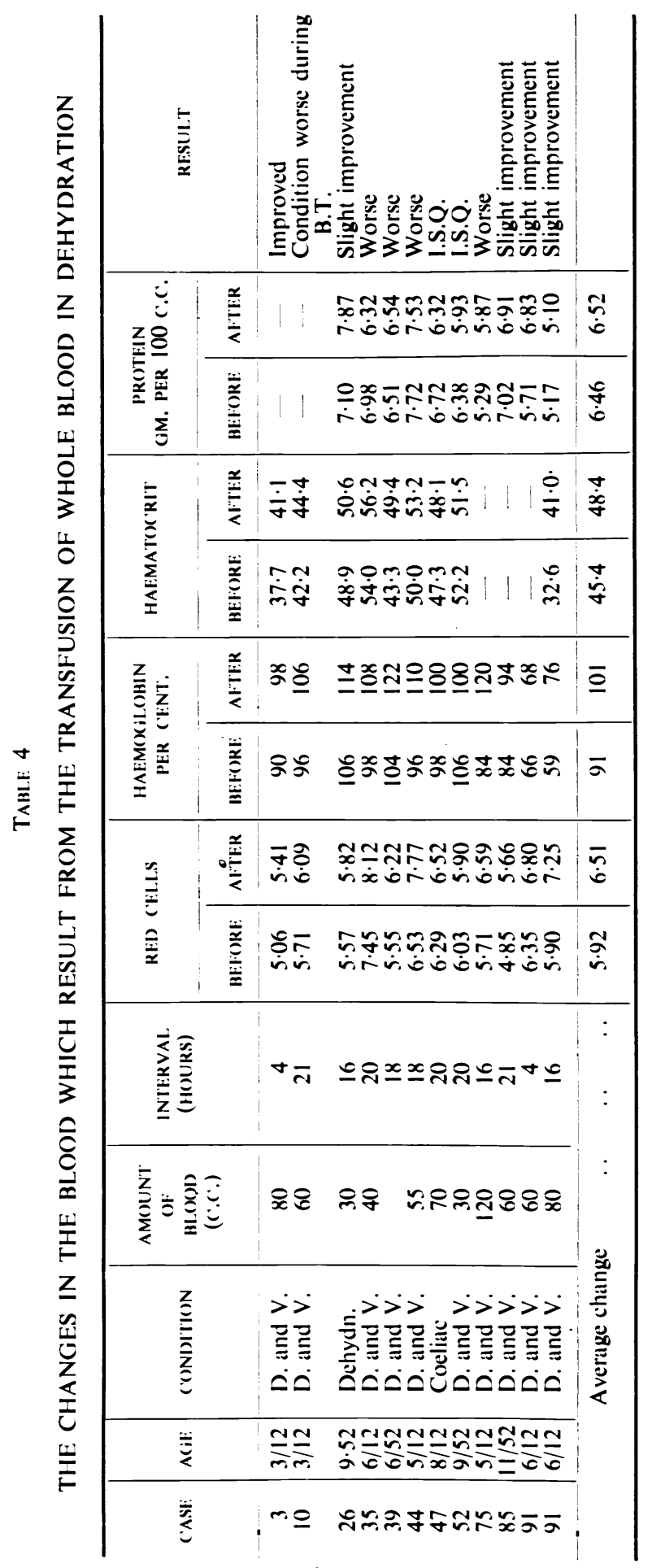


tions were made on twelve infants, and the results of the investigations are set out in table 4. In all but one instance the readings of red cells, haemoglobin and haematocrit increased considerably, irrespective of the size of the transfusion and of the time between the taking of the two blood samples. On the average the plasma protein content was slightly decreased. Five babies were a little improved, two unchanged, and five were definitely worse after transfusion.

Because of the increased concentration of the blood produced by the transfusion of citrated blood, it was thought that if fluid such as normal saline or solutions of 5 or 10 per cent. glucose in normal saline were given simultaneously with the blood, the increase of haemo-concentration would be avoided. Twelve infants were treated in this way and the results are shown in table 5. Six of the cases showed some degree of improvement clinically, but others became much worse. In two instances there was no appreciable change in the concentration of the blood and in only one was there a decreased concentration. Estimations of the plasma protein were made in six cases and the average value rose slightly after transfusion.

In fig. 5 the immediate effect of blood transfusion in a case of gastro-enteritis is illustrated. The interesting feature of the case is the inverse variation of the

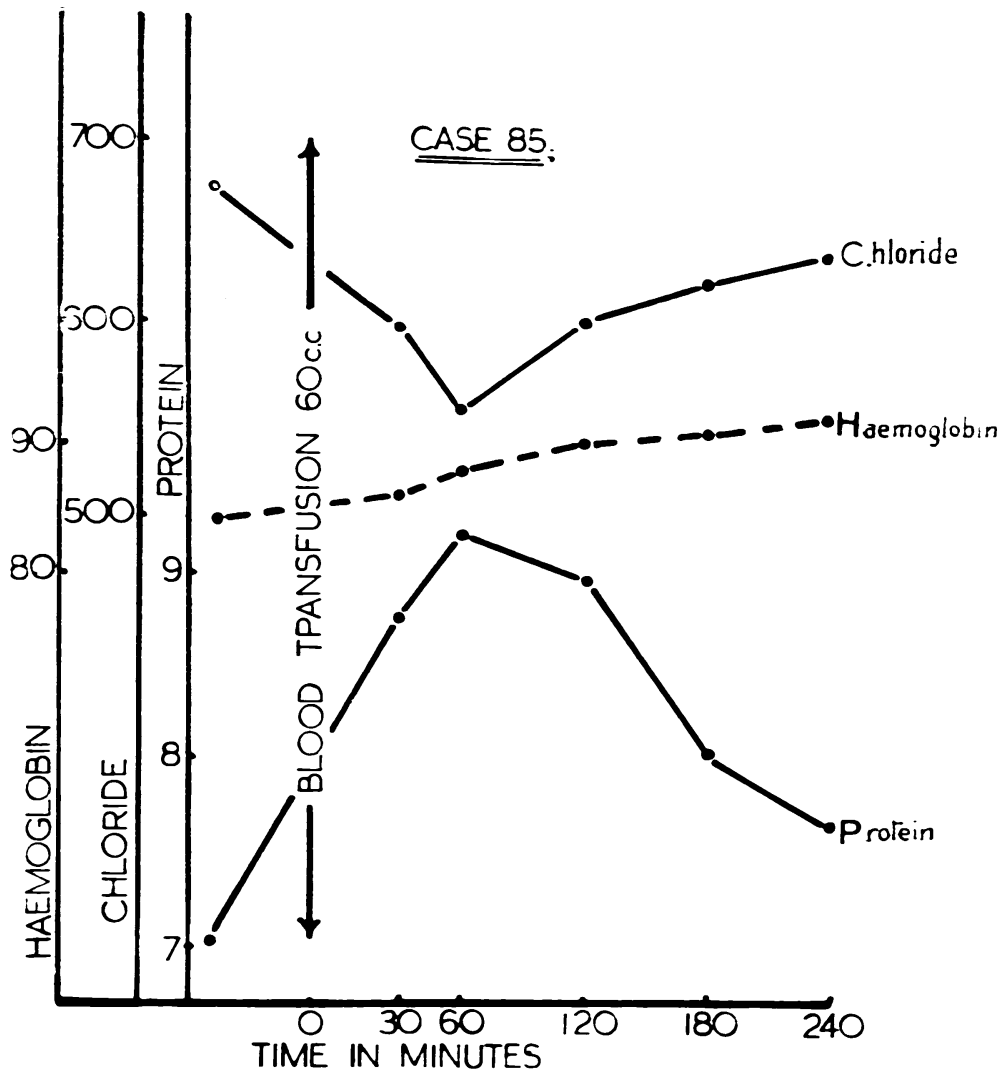

FIG. 5.-Graph showing the effect on blood chloride (C), protein (P), and haemoglobin (H) during a period of four hours following a blood transfusion for dehydration. 
TREATMENT OF DEHYDRATION IN INFANCY

197

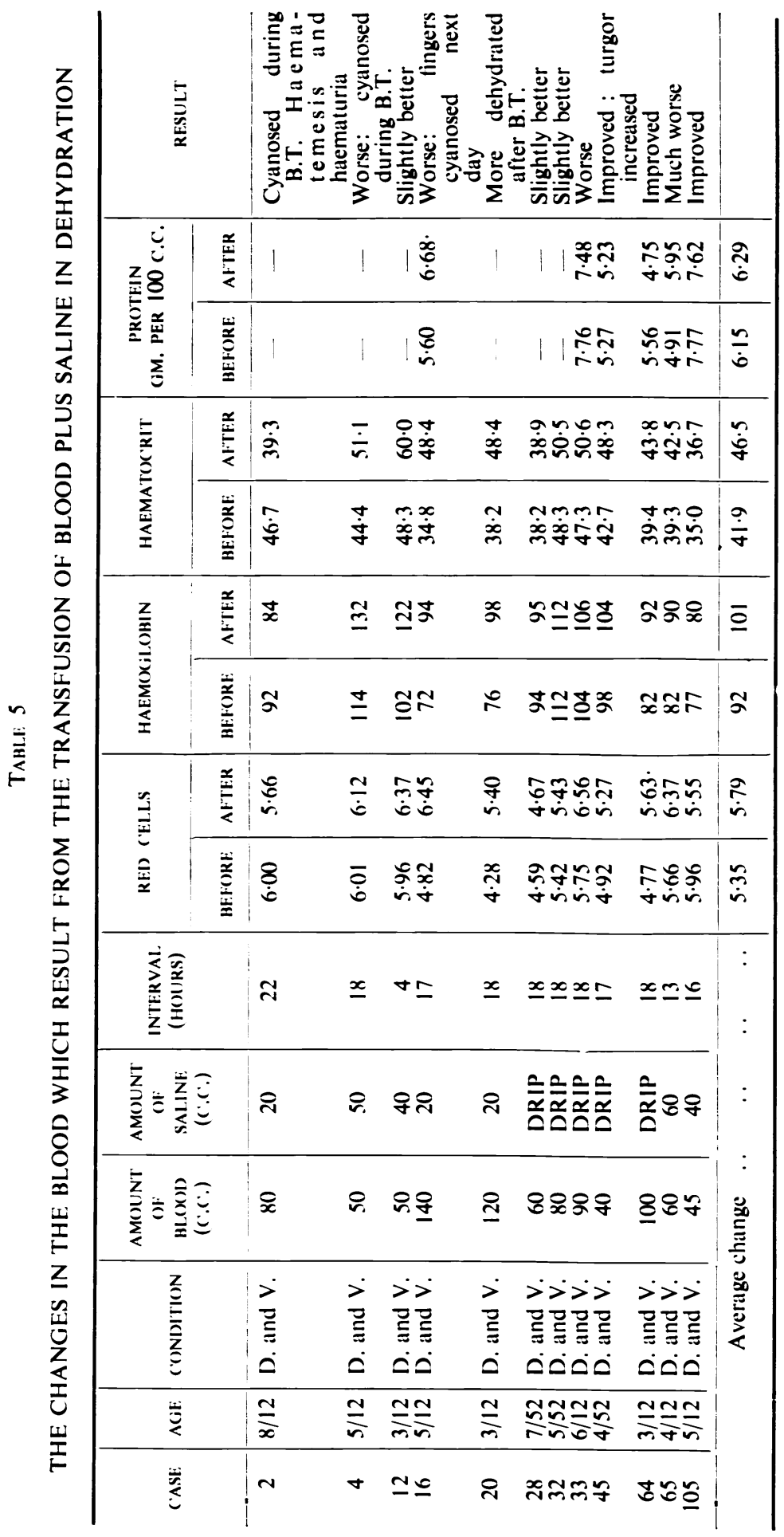


protein and chloride due presumably to an attempt to keep the osmotic pressure of the blood constant.

Contra-indications to blood transfusion. Deterioration following blood transfusion in a patient is shown graphically in fig. 6. The blood picture and clinical condition of this child were growing worse when 60 c.c. of blood were given. On the following day the child was even worse, and was becoming more dehydrated as a result of diarrhoea. A day later still it was impossible to procure a blood sample owing to the extent of the cyanosis and congestion of the feet, and the child died on that day. The graph shows the rise of plasma chloride to $838 \mathrm{mgm}$. per cent. and the increase in blood concentration as the condition of the child deteriorated.

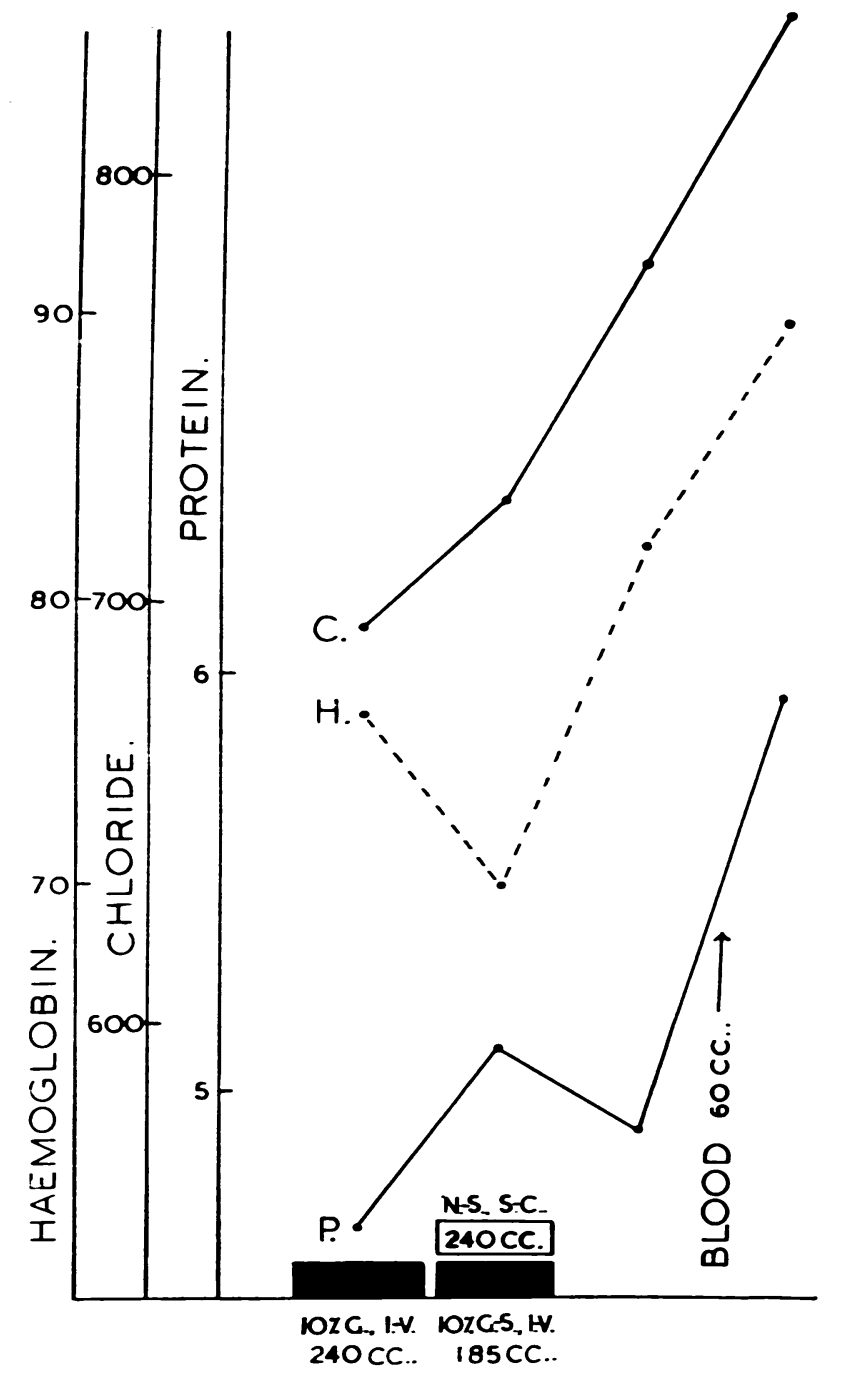


If it is possible to exclude such factors as too large a transfusion, too rapid administration, an error in grouping, cross agglutination between donor and recipient, the presumption that the unsatisfactory results are due to the transfusion itself appears a justifiable one. These factors will now be considered:-

Dosage. Most authorities advise the giving of a maximum of from 10 to 15 c.c. per pound of body weight. (Johnson, 1931; Maizels and Smith, 1934; Goldsmith, 1932: and Spence, 1933.) Holt and McIntosh (1933) state that in dehydration 'it is unwise to inject at one time more than 10 c.c. per pound of body weight.' It is therefore surprising that a few observers have advocated the use of larger amounts; Karelitz (1931) gave up to 40 c.c. per kilogramme but noted severe reactions in many cases. Thomson (1935) found that in babies with marked dehydration amounts larger than 15 c.c per pound could be given with safety, and Powers (1926) considered that babies in general, and those with intestinal intoxication in particular, stood transfusions extraordinarily well. He gauged the dosage of blood by the degree of dehydration, the greater the dehydration the larger the amount of blood given. At the Birmingham Children's Hospital the commonly accepted maximum figure of 15 c.c. per pound is never exceeded. In particularly ill children, the tendency is to give smaller amounts, and in these dehydrated infants the amount given was between 5 and 10 c.c. per pound of actual weight. Neither the previous maximum weight nor the expected weight was taken into account; with this procedure the ill effects noted after transfusion could not be due to the administration of an excessive amount of blood.

RATE OF ADMinistration. The blood was always given as slowly as reasonably possible, from three to four minutes being taken for every 20 c.c., hence any subsequent ill effects were unlikely to be the result of an excessive rate of transfusion. Apart from the obvious danger of overloading the circulation by the too rapid injection of blood, infants become very restless when the blood is given too quickly: whereas, if the blood is given at the rate described, they will take a feed quietly or may even go to sleep during a transfusion. Part of the restlessness is due, no doubt, to pain which results from distension of the vein by which the blood is being given.

BLOOD GROLPING. Apart from grouping both donor and recipient, it was the rule to carry out cross-agglutination tests both between the donor's cells and the recipient's serum, and also between the recipient's cells and the donor's serum. In one instance when the infant subsequently had haematemesis and haematuria, the cross agglutination tests were repeated after transfusion, bu no agglutination was found to occur.

It seems, therefore, that the amount of blood given, the rate of its administration and the grouping can all be excluded as the factors responsible for the unsatisfactory results obtained.

\section{Discussion}

It is interesting to note that some of the cases which improved after transfusion had microcytic anaemia as shown by the low colour index (the lowest 
being $0 \cdot 5$ ), and an apparently normal initial haematocrit reading of under 40 . These infants, before they became dehydrated, must have had a blood count of from 4.0 to 6.0 million red cells, a haemoglobin of about 50 per cent. and a haematocrit reading of from 25 to 30 , but as a result of dehydration and anhydraemia all these values became increased until the haemoglobin and haematocrit readings, at least, were within normal limits. This condition has been referred to as ' masked anaemia.' It is easy to understand why such cases may improve after transfusion, for even after this procedure the ratio of the packed red cells to the plasma fraction of the blood (as determined by the haematocrit) is little, if at all, increased above the normal value. Consequently, the circulation is not embarrassed by an increase in concentration and viscosity of the blood. Unfortunately, it was impossible to obtain haematocrit figures in every patient, but it is instructive to compare initial and subsequent haematocrit readings in eight patients who improved with a similar number who failed to show improvement after transfusion (see tables 4 and 5). The average initial value in those infants who improved was 40.4 and this was increased 3.5 by transfusion to an average figure of 43.9. Two children had subsequent values of over 50 , but the actual increase was only 1.7 and 2.2 respectively. The average amount of blood given was 61 c.c. and the average age of the patients was three months. In the children who became worse after transfusion, the average initial value was 44.4 and the value after transfusion $49 \cdot 5$, an increase of 5.1. In four cases the second reading was over 50 , the average increase in these being 3.9. The amount of blood per transfusion averaged 71 c.c. (for seven cases), the average age being four and a half months. Therefore, not only was the initial value higher in the patients who failed to improve clinically, but in addition the average increase was greater than in those cases which improved. From the figures it can be seen that of the dehydrated children who were transfused those with the greatest haemo-concentration (i.e., the highest haematocrit readings) gave the least favourable clinical results, and they also showed a greater increase in the concentration of their blood after they had received the transfusion.

It is hence of the greatest importance to assess the degree of haemo-concentration present in a dehydrated infant, before deciding whether or not to give a blood transfusion. Moreover, routine blood transfusions in the treatment of dehydration in infancy seem quite illogical, not only in view of the facts revealed in these investigations, but also because in the first two or three days after transfusion the blood volume remains increased solely by the volume of injected red corpuscles (Boycott and Oakley, 1934), and because infusion of whole defibrinated blood to dogs causes plasma rapidly to leave the blood stream (Adolph et al., 1934). There is little weight in the argument that the extra protein introduced by transfusion attracts fluid into the blood stream, because in spite of an increase in the concentration of the blood, the plasma protein may actually fall after transfusion; moreover, if the child's own protein cannot hold fluid in the circulation, it is difficult to believe that a similar concentration of protein from a donor's blood can attract fluid from the tissues into the blood stream. 


\section{PLASMA TRANSFUSION IN THE TREATMENT OF DEHYDRATION}

In the light of the disappointing results and of the increased haemo-concentration following blood transfusion, it was decided to try the effect of transfusion of plasma in cases of extreme dehydration. It was hoped by the use of plasma to give the patient the beneficial stimulus of a blood transfusion without increasing the concentration of his blood by the addition of red cells since it is the plasma fraction of the blood which is reduced in dehydration (Spence, 1933). Karelitz in 1931 mentioned the use of plasma in dehydrated infants whose haemoglobin was over 65 per cent., but he found the preparation of plasma took so long that he abandoned its use. Hartmann (1934) also referred to the use of plasma transfusion in the treatment of starvation oedema.

The plasma used was prepared by centrifuging citrated blood for half an hour at 3,000 revolutions a minute, and it was usual to obtain about 30 c.c. of plasma from each 50 c.c. of citrated blood. Eight patients were treated in this way, and it must be stressed that all were desperately ill. Table 6 shows the degree of concentration of the blood before and after treatment. Four cases had appreciable amounts of 5 per cent. glucose in normal saline given at the same time as, or just after the plasma; the remaining cases had no other fluid parenterally. Of these eight children four eventually died, but so far as the immediate results were concerned, five were clinically improved, two became worse, and the others did not show any change. In six of the cases, haemoconcentration was diminished and as with whole blood transfusions the concentration of plasma protein was, on the average, decreased.

The effects of plasma transfusion in an individual case are shown in fig. 7 and 8 . This child was suffering from gastro-enteritis, and was very toxic and dehydrated. There was marked concentration of the blood (red cells $7 \cdot 17$ millions, haemoglobin 100 per cent., haematocrit not estimated), but the administration of 160 c.c. of an aqueous solution of 10 per cent. glucose ( $X$ in fig. 7) caused no improvement, in fact the red cells rose to 8.02 millions, and haemoglobin to 114 per cent. Subsequent administration of 435 c.c. of glucose and saline ( $Y$ in fig. 7) produced improvement. On the third day, 65 c.c. of plasma were given intravenously. Apart from a pyrexia of $106^{\circ} \mathrm{F}$. no untoward reaction occurred, and there was a further slight improvement in the clinical condition, despite continued diarrhoea and vomiting. However, the blood hecame and remained much less concentrated (red cells about 6.00 millions and haemoglobin 85 per cent.) suggesting that the plasma assisted in retaining a large amount of the injected fluid in the blood stream. The effect of treatment on the urinary output and chloride is shown in fig. 8; the intravenous injection of fluid started a relative diuresis, and when chloride began to be excreted in the urine the plasma chloride fell from $735 \mathrm{mgm}$. to $6,28 \mathrm{mgm}$. per cent., in spite of twenty-four hour's anuria on the ninth day. The clinical condition improved greatly, the child was taking well by mouth, and his tissue turgor was restored almost to normal.

The immediate effects of plasma transfusion are demonstrated in fig. 9 . This infant was very dehydrated and toxic as a result of gastro-enteritis; her 


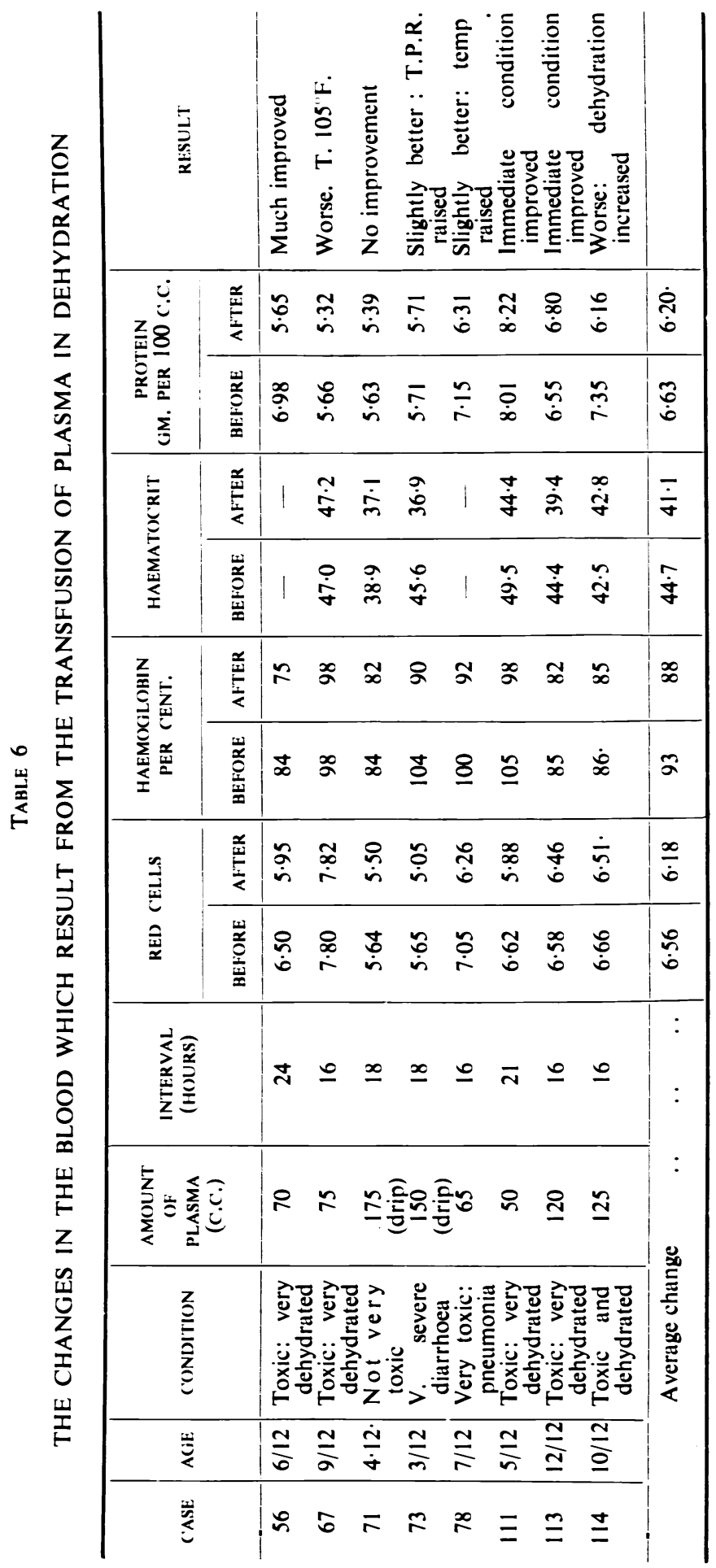




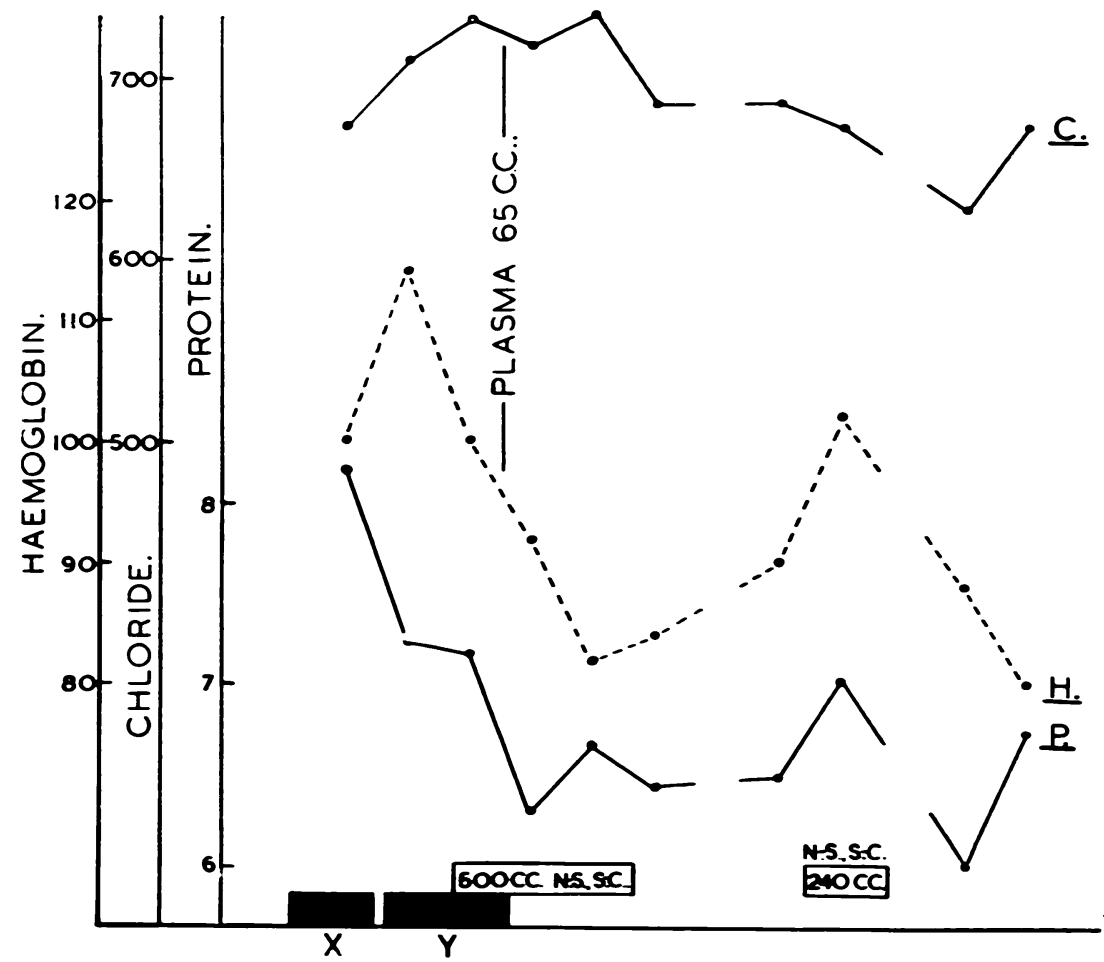


red cells numbered 7.03 millions per c.c., haemoglobin 108 per cent. and haematocrit 48.9. 200 c.c. of normal saline were given subcutaneously, but she remained critically ill and 50 c.c. of plasma with 20 c.c. of normal saline were given intravenously. The concentration of the blood was decreased, the haemoglobin falling to 94 per cent. and the haematocrit to $43 \cdot 3$. There was an

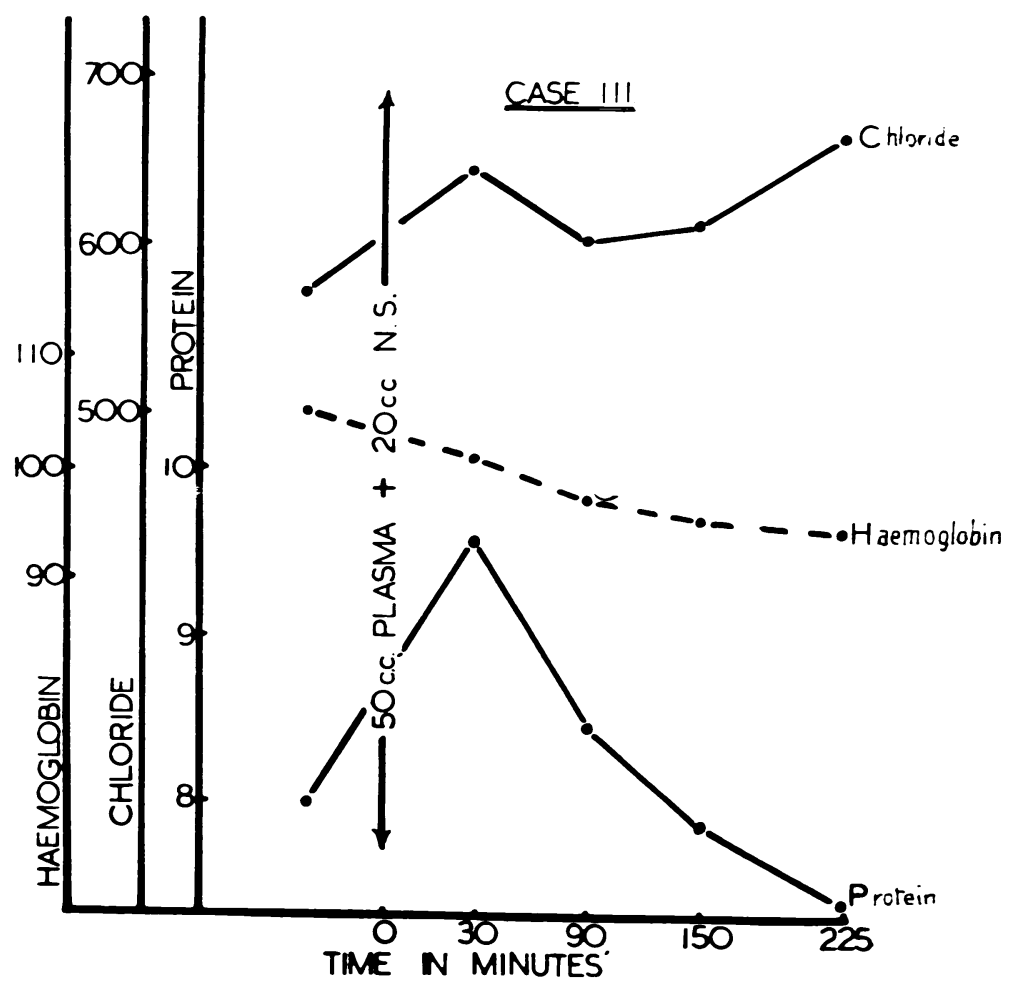

FIG. 9.-Graph showing the effect on haemoglobin (H), blood protein (P), and chloride (C) in dehydration during a period of four hours after administration of blood plasma.

immediate rise in protein concentration and then a fall to a figure which was a little lower than the initial value. In the meantime, there was a considerable improvement in the clinical condition, but later there was a return of the vomiting, she became rapidly worse and eventually died.

\section{CONCLUSIONS}

Solutions of normal ( 0.9 per cent.) saline should not be used as routine treatment in dehydration from gastro-enteritis; in many instances there is an apparent, if not actual, accumulation of chloride in the blood which may increase if further chloride is administered. The routine use of whole blood in the treatment of dehydration is not recommended, as in the majority of cases the blood, which is already concentrated, becomes even more so as the result of treatment. When considering the use of blood transfusion the haematocrit, and preferably the red cell count and haemoglobin concentration in addition, 
should be estimated. If these are raised above normal the case is unsuitable for transfusion. In those patients in whom the haematocrit shows a marked degree of haemo-concentration and who require more drastic treatment than the administration of crystalloid solutions parenterally, transfusions of plasma should be undertaken.

The methods used in these investigations were described in a previous paper (Aldridge, 1941).

In the preparation of this and the preceding paper, thanks are due to Miss Eva Tonks for carrying out a large number of biochemical investigations; to the Nursing Staff of the Hospital without whose loyal co-operation these investigations could not have been carried out; to Prof. Leonard G. Parsons and Dr. J. M. Smellie for criticism and advice, and finally to the Medical Research Council for defraying the expenses of the work.

\section{REFERENCES}

Adolph, E. F., Gerbasi, M. J., and Lepore, M. J. (1934). Amer. J. Physiol., 107, 662.

Aitken, R. S. (1929). J. Phisiol., 67, 209.

Aldridge, A. G. V. (1941). Arch. Dis. Childh., 16, 81.

Ambard, L. (1920). Physiologie normale et pathologique des reins, second ed., Paris.

Boycott, A. E., and Oakley, C. L. (1934). J. Path. Bact., 38, 91.

Boyd, G. (1926). Amer. J. Dis. Child., 31, 514.

Brown, A., and Tisdall, F. F. (1937). Common procedures in the practice of pediatrics, Toronto. Butler, A. M. (1935). Med. Clin. N. Amer., 18, 1205.

Carlton, C. H. (1926). Lancet, 2, 850.

Cooper, E. D. (1937). Arch. Dis. Childh., 12, 347.

de Wesselow, O. L. V. (1924). Int. Clin., 3, 191.

Gamble, J. L., and Ross, S. G. (1924-5). J. clin. Invest., 201, 909.

Goldsmith, H. E. (1932). Northw. med., Seattle, 31, 174.

Hartmann, A. F. (1934). J. Amer. med. Ass., 103, 1349.

Hoag, L. A., and Marples, E. (1931). Amer. J. Dis. Child., 42, 291.

Holt, L. E., and McIntosh, R. (1933). Diseases of infancy and childhood, tenth ed.. New York.

Johnson, F. E. (1931). Arch. Pediat., 48, 197.

Karelitz, S. (1931). Amer. J. Dis. Child., 42, 785.

McIntosh, R., Kajdi, L., and Meeker. D. (1930-31). J. clin. Invest., 9, 333.

Maizels, M., and Smith, J. (1934). Lancet, 1, 1329.

Marriott, W. M. (1934). Sth. med. J., Nashville, 27, 131.

- and Hartmann, A. F. (1933). J. Pediat., 3, 187.

Peters, J. P. (1935). Body Water, London.

Powers, G. F. (1926). Amer. J. Dis. Child., 32, 232.

Sidbury, J. B. (1927). J. Amer. med. Ass., 89, 855.

Spence, J. C. (1933). Disease of infancy and childhood, edited by Parsons and Barling, London. Thomson, M. L. (1935). Arch. Dis. Childh., 10, 109.

Wiener, A. S. (1935). Blood groups and blood transfusions, Springfield. 